\title{
Paint sludge waste co-processing at the ACC Wadi Cement Works in Karnataka, India
}

\author{
S. P. Gautam ${ }^{1}$, P. S. Bundela ${ }^{2}$ \& M. Murumkar ${ }^{3}$ \\ ${ }^{1}$ Central Pollution Control Board, New Delhi, India \\ ${ }^{2}$ Madhya Pradesh Pollution Control Board, India \\ ${ }^{3}$ AFR Regional Supply Chain North Region, ACC Ltd, India
}

\begin{abstract}
Co-processing in a cement kiln is an effective, environmentally friendly and safe technology for the management of hazardous waste, such as paint sludge, because the cement process perforce provides the high temperature and long residence condition required for the complete destruction of the waste. Furthermore, it fully absorbs the energy and material value of the waste without any harmful emissions. Co-processing in cement kilns ranks higher in the waste management hierarchy when compared to other disposal options, such as incineration and landfill. Co-processing is unlike incineration and landfill processing, which leave behind residue that might have harmful impacts on the environment. Thus, co-processing of paint sludge is the best option for an ecologically sustainable solution for paint sludge waste management. The co-processing trial of paint sludge was carried out by Associated Cement Companies (ACC) under the guidance of Karnataka state pollution control board (KSPCB), in the presence of a Toyota Kirloskar Motors Limited (TKML) representative from $8^{\text {th }}$ to $17^{\text {th }}$ April 2008. The trial carried out had three phases, namely pre co-processing, co-processing and post co-processing. The parameters, such as dioxins and furans, total organic carbon (TOC), poly aromatic hydrocarbon (PAH), particulate matter (dust), $\mathrm{Co}_{2}, \mathrm{Co}, \mathrm{O}_{2}, \mathrm{NO}_{\mathrm{x}}, \mathrm{So}_{2}$, $\mathrm{HCl}, \mathrm{HF}, \mathrm{HBr}, \mathrm{NH}_{3}, \mathrm{C}_{6} \mathrm{H}_{6}$ and heavy metal $(\mathrm{Hg}, \mathrm{Sb}, \mathrm{As}, \mathrm{Cd}, \mathrm{Cr}, \mathrm{Co}, \mathrm{Cu}, \mathrm{Pb}, \mathrm{Mn}$, $\mathrm{Ni}, \mathrm{Ti}, \mathrm{V}$ ) emissions, were monitored from the kiln stack during each phase of the co-processing trial. The co-processing trial run results concluded that the waste material, namely paint sludge, can be safely co-processed in cement kilns.
\end{abstract} Keywords: paint sludge waste, co-processing, pyrolysis, landfill, incineration, emissions. 


\section{Introduction}

India is the second fastest growing major economy in the world, with a GDP growth rate of greater than $8 \%$. Due to the boom in the economy and enhanced industrial growth, the management of wastes generated is posing a very serious threat to the society from the health, safety and environmental viewpoint. The generation rate of hazardous wastes in the country, as per the official records, is estimated to be about 4 million tons per annum and that of the Municipal Solid Waste (MSW) is about 40 million tons per annum. There are also numerous nonhazardous wastes from agricultural activities and industries, the generation rate of which is about 400 million tons per annum. Proper measures and guidelines are required for the management of these huge quantities of wastes, whether it be for their disposal or for their gainful utilization. Co-processing refers to the use of waste materials in industrial processes as alternative fuels and raw materials (AFR) to recover energy and material from them. Due to the high temperature and long residence time in cement kilns, all types of wastes can be effectively disposed of without any harmful emissions. Co-processing is a more environmentally friendly and sustainable method of waste disposal as compared to land filling and incineration, because of reduced emissions and no residue after the treatment.

The purpose of the co-processing trial is to demonstrate that the kiln is able to co-process hazardous waste in an environmentally safe and sound manner. The paint sludge from the automobile industry contains heavy metals and other toxic substances, due to which has high pollution potential. Incorrect disposal of paint sludge leads to types of environmental pollution. Recycling and reusing wastes can be one of the best solutions for decreasing pollutant entrance into the environment. Titanium dioxide is one of the compounds that has various applications in different industries, and due to its high costs an economical method for extracting $\mathrm{TiO}_{2}$ from this sludge can be a profitable solution [1]. Paint waste samples ash residue from a thermal treatment process, such as combustion, would be classified as hazardous according to the environment protecting agency (EPA) toxicity characterized leaching procedure (TccP). In addition, the feasibility of generating a classified product from the ash that would be classified as non-hazardous was also tested [2].

The method of producing a combustion product that involves dewatering raw paint sludge from spray paint involves both the operation and adding a desulfuring agent thereto. The resulting material can provide significant and economical full value and sulfur emission control to combustion processes, such as for power plants, while also obviating the need to dispose of waste paint sludge in landfill.

Additionally the process is inexpensive, safe and free of most problems associated with paint sludge drying [3]. The production of large quantities of paint sludge is a serious environmental problem. This work evolved the use of the pyrolysis reaction as a process for deactivating paint sludge that generates a combustible gas solvent liquid phase and an inert solid phase. Pyrolysis appears to be a good alternative for the treatment of paint sludge wastes. The solid phase weight reduction has no significant variation. The alkyd resin had an average 
reduction in the weight solid mass of $70 \%$ latex resin, $75 \%$ and polyurethane resin, 96\% [4-10].

\section{Feeding arrangement for the waste material}

The feeding system installed at the ACC Wadi Cement Works for the waste coprocessing consists of a hoist with a bucket, hopper, belt conveyer, double flap damper and shut off gate. The hoist lifts the waste material packed in bags from the ground level to the second floor of the pre-heater tower. The capacity of the hoist is 3 tons. The volume of the hoist bucket is $0.75 \mathrm{~m}^{3}$. The material is unloaded from the bucket on the feeding platform. The waste packed in bags is then fed into the opening of the feeding chute through a variable speed belt conveyor. A double flap damper is used in order to avoid false air entry.

\section{Co-processing trial}

\subsection{Hazardous waste used for the trial}

M/s. Toyota Kirloskar Motors Limited (TKML), located at Ramnagar, Bangalore is a joint venture between the Toyota Motor Corporation, Japan and the

Table 1: Analysis report of paint sludge from Toyota Kirloskar Motors Limited (TKML).

\begin{tabular}{|l|c|}
\hline Particular & Paint Sludge \\
\hline Proximate analysis & 29.9 \\
\hline Total Moisture (As received) (\%) & 75.2 \\
\hline Volatile Matter (\%) & 22.7 \\
\hline Ash (\%) & 2.1 \\
\hline Fixed Carbon (\%) & 4330 \\
\hline GCV (Cal/Gm) & 0.5 \\
\hline Sulphur (\%) & \\
\hline Ash analysis (\%) & 6.8 \\
\hline SiO2 & 18.0 \\
\hline $\mathrm{A} 2 \mathrm{O} 3$ & 6.2 \\
\hline $\mathrm{Fe} 2 \mathrm{O} 3$ & 0.4 \\
\hline $\mathrm{CaO}$ & 0.4 \\
\hline $\mathrm{MgO} 0.4$ & 0.2 \\
\hline $\mathrm{LOI}(10000 \mathrm{C})$ & 5.5 \\
\hline $\mathrm{SO} 3$ & 0.14 \\
\hline Total Cl & 0.2 \\
\hline $\mathrm{Na} 2 \mathrm{O}$ & 0.2 \\
\hline $\mathrm{K} 2 \mathrm{O}$ & 53.0 \\
\hline TiO2 & 8.5 \\
\hline $\mathrm{BaO}$ & 0.4 \\
\hline P2O5 & \\
\hline
\end{tabular}


Kirloskar Group, India. It is one of the leading vehicle manufacturers in India. The company started production activity in December 1999. The products manufactured are Toyota Innova and Toyota Corolla cars with a capacity of 6000 units per annum. TKML generates paint sludge, chemical sludge and phosphate sludge waste during its manufacturing operations. The hazardous waste from TKML was co-processed during the trial burn conducted at the Associated Cement Companies (ACC) Wadi Cement Works from 8th to 17th April 2008. The paint sludge sample contains $22.7 \%$ ash, which was evaluated for its chemical composition. The ash was made by firing the sample in a furnace at $850^{\circ} \mathrm{C}$, with natural air draft for three hours. The chemical composition of the paint sludge ash is shown in Table 1.

\section{Hazardous waste handling at ACC Wadi Cement Works}

The paint sludge drums were unloaded at Wadi Works with the help of a forklift and stored at designated sites in the storage shed. The workers and supervisors were trained in the handling and safety aspects of hazardous waste well in advance of the trial burn. Concerned personnel were also trained on precautions to be undertaken, emergency measures, potential spill abatement, proper use and upkeep of PPEs, etc. To minimize contact with waste and for easier handling during feeding into the cement kiln system, it was decided to pack the paint sludge waste into bags. The first step was to separate the liquid and solid parts of the waste. This was done by tilting the drums and transferring the contents on to a wire sieve placed on top of mild steel rectangular tank. The tank was made leak proof by lining it with a tarpaulin sheet. Steps were also taken to absorb leakages (if any) with raw meal. The solid part of the waste was then packed into bags. Tarpaulin sheets were spread on the concrete floor of the storage shed and the bags were placed on the tarpaulin sheets to avoid any problems in case of leakage/spillage. The liquid part of the waste was put back into the drums. The drums containing wastewater were kept aside, on the other side of the storage shed, with a proper barricade. The average weight of the bags containing paint sludge waste was found to be $5.45 \mathrm{~kg}$ (approx.)

\section{Storage of paint sludge near kiln 3 during feeding}

An area of $8 \times 5$ square feet at ground level near Kiln 3 was identified for temporary storage of the waste during feeding into the kiln. The floor was covered with a tarpaulin sheet and the area was barricaded.

\section{Outline of monitoring plan during the co-processing trial}

The purpose of the co-processing trial is to demonstrate that the kiln is able to co-process hazardous waste in an environmentally friendly manner. The emission monitoring results from the trial burn serve as a basis to demonstrate the environmentally sound performance of co-processing to the authorities and 
Table 2: $\quad$ Summary of co-processing trial schedule.

\begin{tabular}{|c|c|c|c|}
\hline \multirow[t]{2}{*}{ S. No. } & \multicolumn{2}{|c|}{ Date } & \multirow[t]{2}{*}{ Phase } \\
\hline & From & To & \\
\hline 1. & $8^{\text {th }}$ Apr. 08 & $14^{\text {th }}$ Apr. 08 & $\begin{array}{l}\text { Pre Co processing Phase for Paint } \\
\text { Sludge }\end{array}$ \\
\hline 2. & $14^{\text {th }}$ Apr. 08 & $16^{\text {th }}$ Apr. 08 & $\begin{array}{l}\text { During Co processing Phase With } \\
\text { Paint Sludge }\end{array}$ \\
\hline 3. & $16^{\text {th }}$ Apr. 08 & $17^{\text {th }}$ Apr. 08 & $\begin{array}{l}\text { Post Co processing Phase for Paint } \\
\text { Sludge }\end{array}$ \\
\hline
\end{tabular}

other stakeholders in the waste disposal activity. The co-processing trial of paint sludge waste from TKML, which was conducted between 8th to 17th April, was carried out in three phases (namely pre co-processing, co-processing and post coprocessing). There was a kiln stabilization period with conventional fuel for a span of 24 hours before the start of the trial

\section{Summary of the co-processing trial schedule}

The schedule for the co-processing trial of paint sludge waste from Toyota Kirloskar Motors Limited (TKML) at ACC Wadi Cement works is shown in Table 2.

\section{Results and discussions}

\subsection{Standard process parameters during co-processing trial}

During the pre co-processing, co-processing and post co-processing phase of the trial burn:

- The kiln feed rate, on average, was 230.8, 208.4 and 205.8 tons per hour.

- The coal feed rate to calciner, on average, was 17.9, 16.9 and 16.9 tons per hour.

- The coal feed rate to the main burner of kiln, on average, was 10.8, 8.5 and 7.6 tons per hour.

During the period of the co-processing trial, there were some disturbances in the process, which were rectified by taking kiln stoppages. On investigation, it was discovered that the disturbances were not due to waste co-processing in kiln, but due to some other process related technical issues. Computer printouts of the hourly process chart of kiln 3 sections were taken during the entire period of the co-processing trial. The following parameters were monitored [11]. 1. Kiln Torque (Kilo Watt - KW), 2. Kiln Feed Rate (tons per hour - TPH), 3. Coal Feed Rate to Kiln (tons per hour - TPH), 4. Coal Feed Rate to Calciner (tons per hour - TPH), 5. Last Cyclone Bottom Temperature $\left({ }^{\circ} \mathrm{C}\right)$ Stream 1, 6. Last Cyclone Bottom Temperature $\left({ }^{\circ} \mathrm{C}\right)$ Stream 2, 7. Kiln Speed (revolutions per minute - RPM), 8. Burning Zone Temperature $\left({ }^{\circ} \mathrm{C}\right)$, 9. Pre Heater Outlet Temperature $\left({ }^{\circ} \mathrm{C}\right)$ Stream 1,10 . Pre Heater Outlet Temperature $\left({ }^{\circ} \mathrm{C}\right)$ Stream 2 , 
11. Pre Heater Draft (mm WC) String 1, 12. Pre Heater Draft (mm WC) String 2, 13. Pre Heater Outlet $\mathrm{O}_{2}(\%)$ String 1, 14. Pre Heater Outlet $\mathrm{O}_{2}(\%)$ String 2, 15. Pre Heater Outlet CO (\%) String 1, 16. Pre Heater Outlet CO (\%) String 2, 17. Back End Temperature $\left({ }^{\circ} \mathrm{C}\right), 18$. Tertiary Air Temperature $\left({ }^{\circ} \mathrm{C}\right), 19$. Secondary Air Temperature $\left({ }^{\circ} \mathrm{C}\right)$

\subsection{Sampling conditions during co-processing trials}

The sampling conditions and the stack parameters for Wadi kiln 3 were estimated during the trial as per the sampling procedure of the United States Environmental protection agency (Table 3 ).

\subsection{Results of emission monitoring during co-processing trial}

The detailed results of the monitoring carried out during the co-processing trial and the summary of the results are elaborated in Table 4. It is to be noted that the results are the average values for the number of samples collected at the time of emission monitoring during the trial.

\subsubsection{Dioxins and furans}

Sampling procedure - USEPA Method No. $23 \mathrm{~A}$ - the monitoring results for each phase of the trial are found to be within the prescribed norms of the Central Pollution Control Board (CPCB). It was also found that there was a marginal change in emissions during the co-processing of waste and after co-processing of the waste.

Table 3: $\quad$ Sampling conditions and stack parameters during the co-processing trial.

\begin{tabular}{|c|c|c|c|}
\hline Operation Mode & Unit & \multirow{2}{*}{\multicolumn{2}{|c|}{$\begin{array}{c}\text { Average Reading } \\
\text { Stream } 2\end{array}$}} \\
\hline \multicolumn{2}{|l|}{ Stream 1} & & \\
\hline Stack Diameter & {$[\mathrm{m}]$} & \multicolumn{2}{|c|}{3.75} \\
\hline Cross Section Area & {$\left[\mathrm{m}^{2}\right]$} & \multicolumn{2}{|c|}{11.05} \\
\hline Pressure & {$[\mathrm{mm} \mathrm{Hg}]$} & \multicolumn{2}{|c|}{719} \\
\hline Gas Temperature & {$\left[{ }^{\circ} \mathrm{C}\right]$} & 141 & 138 \\
\hline Moisture & [volume $\%$ ] & 18.5 & 19.0 \\
\hline Oxygen Content & [volume \%] & 9.6 & 9.8 \\
\hline Carbon Dioxide Content & [volume \%] & 20.0 & 20.4 \\
\hline Carbon Monoxide & {$\left[\mathrm{mg} / \mathrm{Nm}^{3}\right]$} & 162 & 190 \\
\hline Exhaust Gas Velocity & {$[\mathrm{m} / \mathrm{s}]$} & 20.88 & 21.46 \\
\hline $\begin{array}{l}\text { Exhaust Gas Volume } \\
\text { (Stack Conditions) }\end{array}$ & {$\left[\mathrm{m}^{3} / \mathrm{h}\right]$} & 830606 & 853679 \\
\hline $\begin{array}{l}\text { Exhaust Gas Volume } \\
\text { (Normal, Wet) }\end{array}$ & {$\left[\mathrm{m}_{\mathrm{n}, \mathrm{wet}}^{3} / \mathrm{h}\right]$} & 565133 & 580831 \\
\hline $\begin{array}{l}\text { Exhaust Gas Volume } \\
\text { (Normal, Dry) }\end{array}$ & {$\left[\mathrm{m}_{\mathrm{n}, \mathrm{dry}}^{3} / \mathrm{h}\right]$} & 460583 & 470473 \\
\hline
\end{tabular}


Table 4: $\quad$ Summary of co-processing trial results.

\begin{tabular}{|c|c|c|c|c|c|c|c|}
\hline \multirow[b]{2}{*}{ Parameter } & \multicolumn{5}{|c|}{ Measured stack emission during trial } & \multirow{2}{*}{$\begin{array}{l}\text { Change in } \\
\text { emission } \\
\text { during co- } \\
\text { processing } \\
\text { of waste }\end{array}$} & \multirow{2}{*}{$\begin{array}{l}\text { Change in } \\
\text { emissions } \\
\text { after co- } \\
\text { processing } \\
\text { of waste }\end{array}$} \\
\hline & Units & Norm* & $\begin{array}{l}\text { Pre Co- } \\
\text { processing }\end{array}$ & $\begin{array}{c}\text { Co- } \\
\text { processing }\end{array}$ & $\begin{array}{l}\text { Post Co- } \\
\text { processing }\end{array}$ & & \\
\hline Dioxin \& Furan & $\begin{array}{c}\text { ng } \\
\text { TEQ/Nm3 } \\
\end{array}$ & 0.1 & 0.006 & 0.006 & 0.005 & -0.0005 & -0.0015 \\
\hline TOC & $\mathrm{mgC} / \mathrm{Nm} 3$ & 20 & 3.69 & 2.97 & 3.93 & -0.72 & 0.235 \\
\hline $\mathrm{HCl}$ & $\mathrm{mg} / \mathrm{Nm} 3$ & 50 & 8.50 & ND & 22.01 & 0 & 0 \\
\hline $\mathrm{HF}$ & $\mathrm{mg} / \mathrm{Nm} 3$ & 4 & - & - & - & 0 & 0 \\
\hline $\mathrm{SO} 2$ & $\mathrm{mg} / \mathrm{Nm} 3$ & 200 & 22.67 & 0 & 7.68 & -22.67 & -14.99 \\
\hline SPM & $\mathrm{mg} / \mathrm{Nm} 3$ & - & 228.91 & 259.84 & 275.52 & 30.93 & 46.61 \\
\hline $\mathrm{CO}$ & $\mathrm{mg} / \mathrm{Nm} 3$ & 100 & 215.20 & 148.76 & 157.69 & -66.44 & -57.51 \\
\hline NOx & $\mathrm{mg} / \mathrm{Nm} 3$ & 400 & 279.08 & 502.43 & 486.95 & 223.35 & 207.865 \\
\hline Mercury & $\mathrm{mg} / \mathrm{Nm} 3$ & 0.05 & 0.002 & 0.001 & 0.002 & 0.00 & 0.00 \\
\hline $\begin{array}{l}\text { Heavy Metal } \\
\text { (ex. Cd \& } \mathrm{Tl} \text { ) }\end{array}$ & $\mathrm{mg} / \mathrm{Nm} 3$ & 0.5 & 0.081 & 0.035 & 0.087 & -0.046 & 0.006 \\
\hline
\end{tabular}

* Central pollution control Board norms for common hazardous waste incineration.

\subsubsection{Total organic compounds}

Sampling procedure - USEPA Method No. 25 A - continuous online measurement for 24 hours. Flue gas is sampled via a heated probe and is passed through the hydrogen flame. The organic compounds gets ionization and the strength of ionization is reflected as ionization peaks in the TOC analyzer screen, and the peak area gives us the TOC content. The average emissions results during each phase of the trial were found to be well within the prescribed standard of the CPCB. A marginal change in emissions was also seen during the co-processing and after co-processing of the waste.

\subsubsection{Hydrogen chloride and hydrogen fluorides}

Sampling procedure - an integrated sample is extracted from the source and passed through a heated probe and filter into dilute sulfuric acid and dilute sodium hydroxide solutions, which collect the gaseous hydrogen halides and halogens respectively. The filter collects particulate matter, including halide salts but is not routinely recovered and analyzed. The hydrogen halides are soluble in the acidic solution and form chloride $(\mathrm{Cl})$, bromide $(\mathrm{Br})$ and fluoride $(\mathrm{F})$ ions. The halogens have a very low solubility in the acidic solution and pass through to the alkaline solution where they are hydrolyzed to form a proton $\left(\mathrm{H}^{+}\right)$, the halide ion, and the hypohalous acid ( $\mathrm{HClO}$ or $\mathrm{HBrO})$. Sodium thiosulfate is added in excess to the alkaline solution to assure reaction with the hypohalous acid to form a second halide ion such that two halide ions are formed for each molecule of halogen gas. The halide ions in the separate solutions are measured by ion chromatography. Hydrogen chloride and hydrogen fluoride were monitored during all three phases of the trial. The monitoring results for the coprocessing and post co-processing of the trial are found to be non-detectable. 


\subsubsection{Carbon monoxide, nitrogen and sulphur oxides and particulates}

Sampling procedure $-\mathrm{NO}_{\mathrm{x}}, \mathrm{O}_{2}, \mathrm{CO}_{2}$ - Excess Air Fraction - USEPA Method No. $7 \mathrm{E}$ - instrumental method using a portable digital flue gas analyzer made by Quintox. Orsat Apparatus is used to determine the $\mathrm{O}_{2}$ and $\mathrm{CO}_{2}$. Flue gas is collected in the bladder and it is allowed to pass through $\mathrm{KOH}$ solution so that the $\mathrm{CO}_{2}$ present in the flue gas gets absorbed. The flue gas is again passed through pyrogalal solution so that the $\mathrm{O}_{2}$ in the flue gas will get observed in it. $\mathrm{CO}$ is analyzed through the flue gas analyzer as it cannot be determined by the above method, since the detection limit is $0.2 \%(1 \%=10,000 \mathrm{ppm}$, hence it is determined by the flue gas analyzer). $\mathrm{SO}_{2}$ - USEPA Method No. $6 \mathrm{~A} / \mathrm{B}-$ a gas sample is extracted from a sampling point in the stack. The $\mathrm{SO}_{2}$ in the flue gas is absorbed in $50 \mathrm{ml}$ of $6 \% \mathrm{H}_{2} \mathrm{O}_{2}$. The $\mathrm{SO}_{2}$ and the sulfur trioxide, including those fractions in any sulfur acid mist, are separated. The $\mathrm{SO}_{2}$ fraction is measured by the barium-thorium titration method. Particulate matter - USEPA Method No. 17 - particulate matter is withdrawn iso-kinetically from the source and collected on glass. The fiber filter is maintained at stack temperature. For these, 1000 liters of flue gas is collected and made to pass through the thimble, the weight of which is known to us after drying. After sampling, the thimble is dried and weighed to find the percentage of PM. The results of $\mathrm{CO}$ were found to be above the prescribed standard of CPCB during all three phases of the trial. The $\mathrm{SO}_{2}$ emission level was found to be zero during co-processing, pre co-processing and post co-processing, which is within the prescribed standard of the CPCB. The emission level of NOx was found to be above the prescribed standard of the $\mathrm{CPCB}$ during co-processing and post co-processing, but it was found to be within the prescribed standard during the pre co-processing trial. There is no limit of suspended particulate matter given by the CPCB. However, during trials it was detected at the level that causes harm to the environment.

\subsubsection{Metals}

Sampling procedure - Hg and Heavy Metals - USEPA Method N. 29 - the measurements of the heavy metals, namely Arsenic, Cadmium, Cobalt, Chromium, Copper, Mercury, Manganese, Nickel, Lead, Antimony, Tin, Thallium, Vanadium and Zinc, are given in Table 4. The results indicate that the emissions are within the given limits of the guidelines. A stack sample is withdrawn iso-kinetically from the source, particulate emissions are collected in the probe and on a heated filter, and gaseous emissions are then collected in an aqueous acidic solution of hydrogen peroxide (analyzed for all metals including $\mathrm{Hg}$ ) and an aqueous acidic solution of potassium permanganate (analyzed only for $\mathrm{Hg}$ ). The recovered samples are digested, and appropriate fractions are analyzed for $\mathrm{Hg}$ by cold vapor atomic absorption spectroscopy (CVAAS) and for $\mathrm{Sb}, \mathrm{As}, \mathrm{Cd}, \mathrm{Cr}, \mathrm{Co}, \mathrm{Cu}, \mathrm{Pb}, \mathrm{Mn}, \mathrm{Ni}$ and $\mathrm{Tl}$ by inductively coupled argon plasma emission spectroscopy (ICAP) or atomic absorption spectroscopy (AAS). Graphite furnace atomic absorption spectroscopy (GFAAS) is used for the analysis of $\mathrm{Sb}, \mathrm{As}, \mathrm{Cd}, \mathrm{Co}, \mathrm{Pb}, \mathrm{Se}$ and $\mathrm{Tl}$ if these elements require greater analytical sensitivity than can be obtained by ICAP. If one so chooses, AAS may be used for analysis of all listed metals if the resulting in-stack method detection 
limits meet the goal of the testing program. Similarly, inductively coupled plasma-mass spectroscopy (ICP- MS) can be used for the analysis of Sb, As, Cd, $\mathrm{Cr}, \mathrm{Co}, \mathrm{Cu}, \mathrm{Pb}, \mathrm{Mn}, \mathrm{Ni}$ and $\mathrm{Tl}$. The mercury, heavy metals, $\mathrm{Cd}$ and $\mathrm{Ti}$ were found in all three phases of the trial to be within the prescribed norm of the CPCB. A marginal change in emissions was also seen during the co-processing and after co processing of the waste.

\section{Conclusion}

The objective of this project was to perform a co-processing trial to demonstrate that the cement kiln is able to co-process hazardous wastes in an irreversible and environmental sound manner, i.e. with no influence on the emissions when traditional fuel is partly replaced by hazardous waste.

The hazardous waste, namely, paint sludge is generated by Toyota Kirloskar Motors Limited, Bangalore. TKML generates paint sludge from its manufacturing process and it is classified as hazardous as per HWM Rules. The co-processing trial was carried out together by ACC and TKML from 8th to 17th April, 2008. The trial for paint sludge was carried out in three phases, namely, pre co-processing, co-processing and post co-processing. The emission monitoring was carried out. The monitoring results are summarized in Table 5 where the incremental variation in the emission during co-processing and post co-processing as compared with the baseline measurements are compared with the central pollution control board (CPCB) Norms for the Common Hazardous Waste Incinerators. The Central Pollution control board (CPCB) guideline on Common Hazardous Waste Incinerator provides emission standards for each parameter during incineration of waste. The analysis results of the stack parameters revealed that the emission values are well the standards set by CPCB for the Common Hazardous Waste Incinerators. The test results concluded that the emissions were independent of the usage of the waste materials in the cement process. The cement process perforce requires high temperature in the kiln of around $1400-1450^{\circ} \mathrm{C}$ with a long residence time of $4-5 \mathrm{sec}$. Such high temperature conditions ensure that no noxious emissions take place during the co-processing of the waste materials. The advantages of high temperature cement kilns are widely utilized around the world and co-processing is regarded to be one of the most cost-effective and environment friendly and viable waste management technologies available.

\section{Acknowledgements}

The authors are thankful to ACC Wadi Cement works staffs for laboratory facilities and also thank the Karnataka Pollution Control Board for their support.

\section{References}

[1] Khezri, S. M. \& Bloorchian, A. A., 2009. Case study: Paint sludge of saipa paint shop. Env. Engg. Mang. J. 8 (1), pp. 141-145. 
[2] Balasco, A.A., Bodek, I., Goldman, M.E., Mazrimas, M.J. \& Rossetti, M., Development of a new process for treatment of paint sludge wastes final report. May 1986-Dec 1987. http// handle.dtic.mip/100.2/ADA 197657. 1987.

[3] Joe, P., Denial, M. \& Louis, M., Processing paint sludge to produce a combustion fuel products agent BUTZEL LONT: IP Docketing Dept origin: ANN ARDOR MI us, IPCB class: Ac 10 L 110 FI uspc Class:44311.

[4] Muniz, L.A.R., Costa, A.R., Steffani, E., Zatters, A.J., Hofsetz, K., Bossardi, K. \& Valentini, L., A sludge of paint sludge deactivation by pyrolysis reactions. Braz. J. Chem. Engg. 20 (1), pp. 67-72, 2003.

[5] Erdman, J. \& Johnson, K., Low temperature thermal stripping and volume reduction of weight with a hollow screw Indirect heat Exchange processor. Environmental Conference, Proceedings of Association of the pulp and Paper Industry, pp. 71-73, 1989.

[6] Kim, B.R., Kalis, E.M., Salmeen, I.T., Kruge, C.W., Demir, I., Carlson, S.L. \& Abadi, M. R., Paint sludge chars for adsorption of selected paint solvents. J. Envir. Engg. 5, pp. 56-45, 1996.

[7] Kim, B.R., Podsiadlik, D.H., Yeh, D.H., Salmeen, I.T. \& Briggs, L.M., Evaluating conversion of automotive paint spray booth scrubber to an activated sludge system for removing paint volatile of compound from air. Water Environ. Res. 69 (7), pp. 1211-1221, 1997.

[8] Mitchell, D. B. \& Schweers, M.E., Waste reduction using organic polymers. Poll. Engg. Pp.84-87.1989.

[9] Nakouzi, S., Mielewski, D., Ball, J. C., Kim, B.R., Salmeen, I.T., Bauer, D. \& Narula, C.K., No to paint sludge recycling: Reclaim of paint sludge components as Ceramic composites and their application reinforcement of metal and polymers. J. Materials Res. 13 (1), pp. 53-60. 1998.

[10] Sodero, S. F., Berruti, F. \& Behie, L.A., 1996. Utrapyrolitic Cracking of polyethylene-a High yield reduction method. Chem. Engg. Sci. 51(11), pp. 2805-2816.

[11] Guatam, S.P., Bundela P.S. \& Chawla V. Co- processing of Plastic Waste with coal in the cement Kiln. J. of Solid Waste Technol. Manag. $24^{\text {th }}$ Conference 14-17 ${ }^{\text {th }}$ March, Philadelphia, USA. 24, pp.1173-1179, 2009. 